\title{
First record of the Amazonian tiny tree toad Amazophrynella minuta (Melin, 1941) (Anura: Bufonidae), for Venezuela
}

\author{
Fernando J. M. Rojas-Runjaic ${ }^{1 *}$, Santiago Castroviejo-Fisher ${ }^{2,3}$ and César L. Barrio-Amorós ${ }^{4}$ \\ 1 Fundación La Salle de Ciencias Naturales, Museo de Historia Natural La Salle. Apartado Postal 1930, Código Postal 1010-A, Caracas, DC, \\ Venezuela. \\ 2 American Museum of Natural History, Department of Herpetology. Central Park West at 79th Street, 10024-5192, New York, U.S.A. \\ 3 Pontifícia Universidade Católica do Rio Grande do Sul, Laboratório de Sistemática de Vertebrados. Porto Alegre, RS, Brazil. \\ 4 Instituto de Biodiversidad Tropical, Apartado Postal 210, 8800, San Isidro del General, Costa Rica. \\ * Corresponding author. E-mail: rojas_runjaic@yahoo.com
}

\begin{abstract}
Amazophrynella minuta is a small toad widely distributed in the lowlands and midlands of the Amazon and Guiana regions. Herein we report the first record of this species from Venezuela based on a single specimen from Raudal de Danto, Río Cuao, northwestern Amazonas state. This record extends the distribution of the species more than $500 \mathrm{~km}$ from the closest known localities in Colombia and Brazil
\end{abstract}

Amazophrynella minuta is a small toad of the family Bufonidae. It was originally described as a member of the genus Atelopus but in the last decades has been relocated to different genera (see Frost 2013 for a review of its taxonomic history). This species is currently known from many localities across the lowlands and midlands of the Amazon rainforest of Bolivia, Brazil, Peru, Ecuador, Colombia, Guyana and French Guiana (Ávila et al. 2012; Fouquet et al. 2012; Frost 2013). Fouquet et al. (2012) reported this species from Venezuela (in the Andean piedmont of the Llanos region), however, this record was based on an error of identification (A. Fouquet personal communication to SCF).

Herein, we report for the first time the presence of Amazophrynella minuta from Venezuela on the basis of a single specimen (Figure 1) collected during a herpetological survey conducted by the Museo de Historia Natural La Salle (MHNLS). The specimen is housed at the herpetological collection of the aforementioned institution under the code MHNLS 19913. Collecting permit \#4156 (period 2009-2010) was issued to FJMRR by Ministerio del Poder Popular para el Ambiente of Venezuela.

The specimen (an adult female; SVL: $15.8 \mathrm{~mm}$ ), was found by us near Raudal de Danto, Río Cuao, Autana municipality, Amazonas state, Venezuela $\left(05^{\circ} 03^{\prime} 03.1^{\prime \prime}\right.$ N, 67³4'01.4" W; 115 m; Figure 2), on July 12, 2010 at aproximately 22:00 h, in the leaf-litter near a small creek in primary rainforest (Figure 3). This specimen represents the first record of Amazophrynella minuta for Venezuela, extending its distribution approximately $510 \mathrm{~km}$ NNE from Mitu, Rio Vaupés, Department of Vaupés, Colombia, and 555 km N from Taracúa, Rio Uaupés, Amazonas state, Brazil (type locality), the two closest known localities. The presence of this bufonid in Amazonas, Venezuela is not completely unexpected because the herpetofauna of this region has many Amazonian elements (Barrio-Amorós

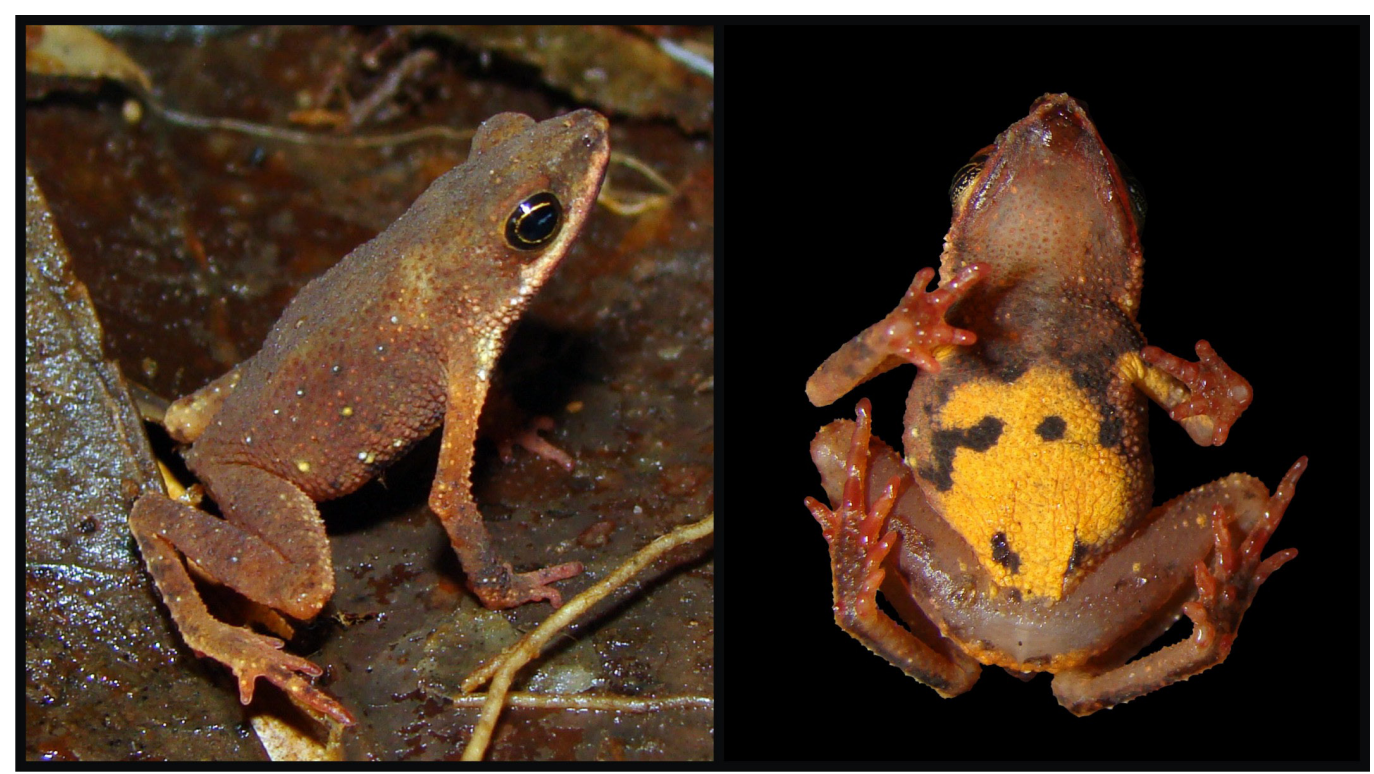

FIGURE 1. Dorso-lateral and ventral photographs of the first specimen of Amazoprhynella minuta (MHNLS 19913; adult female, SVL: 15.8 mm) recorded from Venezuela. 


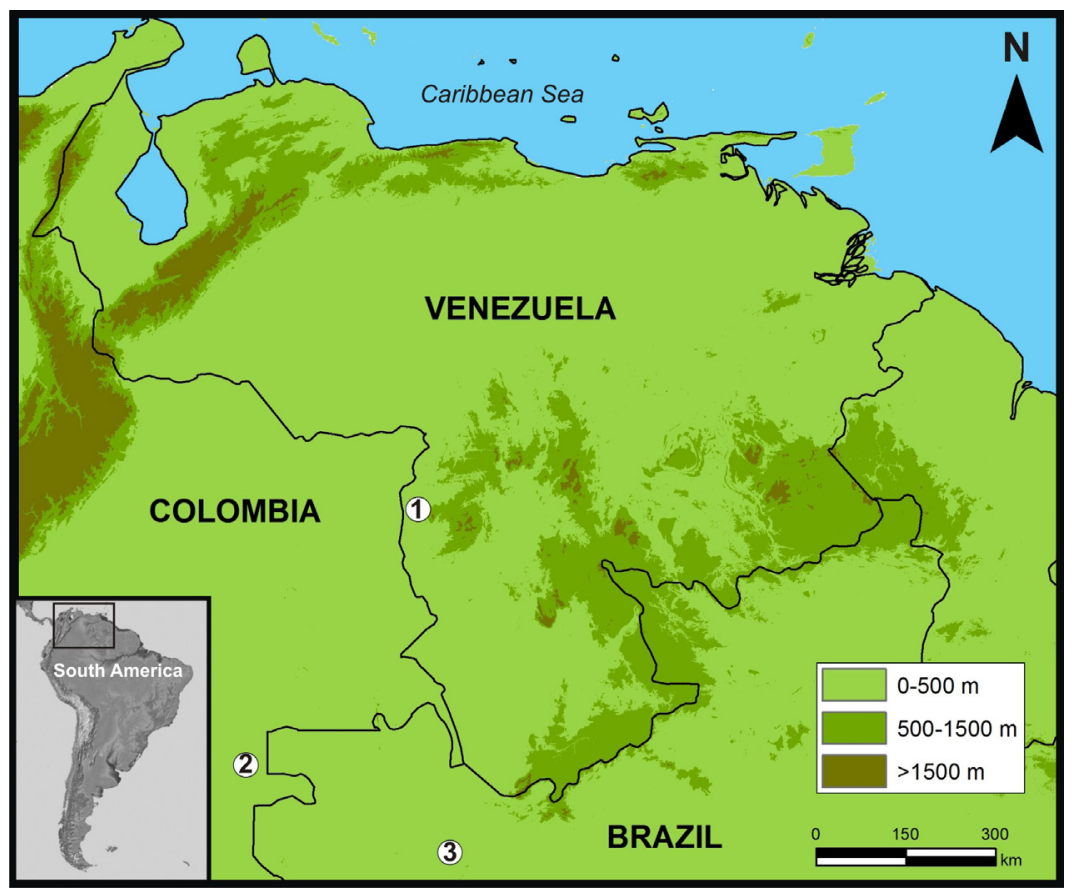

FIGURE 2. Map of northern South America showing the first record of Amazophrynella minuta (MHNLS 19913) from Venezuela (1), near Raudal de Danto, Autana municipality, Amazonas state, $05^{\circ} 03^{\prime} 03.1^{\prime \prime}$ N, 67³4'01.4” W; 115 m. Closest known localities in Colombia (2: Mitu, Rio Vaupés, Department of Vaupés) and Brazil (3: Taracúa, Rio Uaupés, Amazonas state).

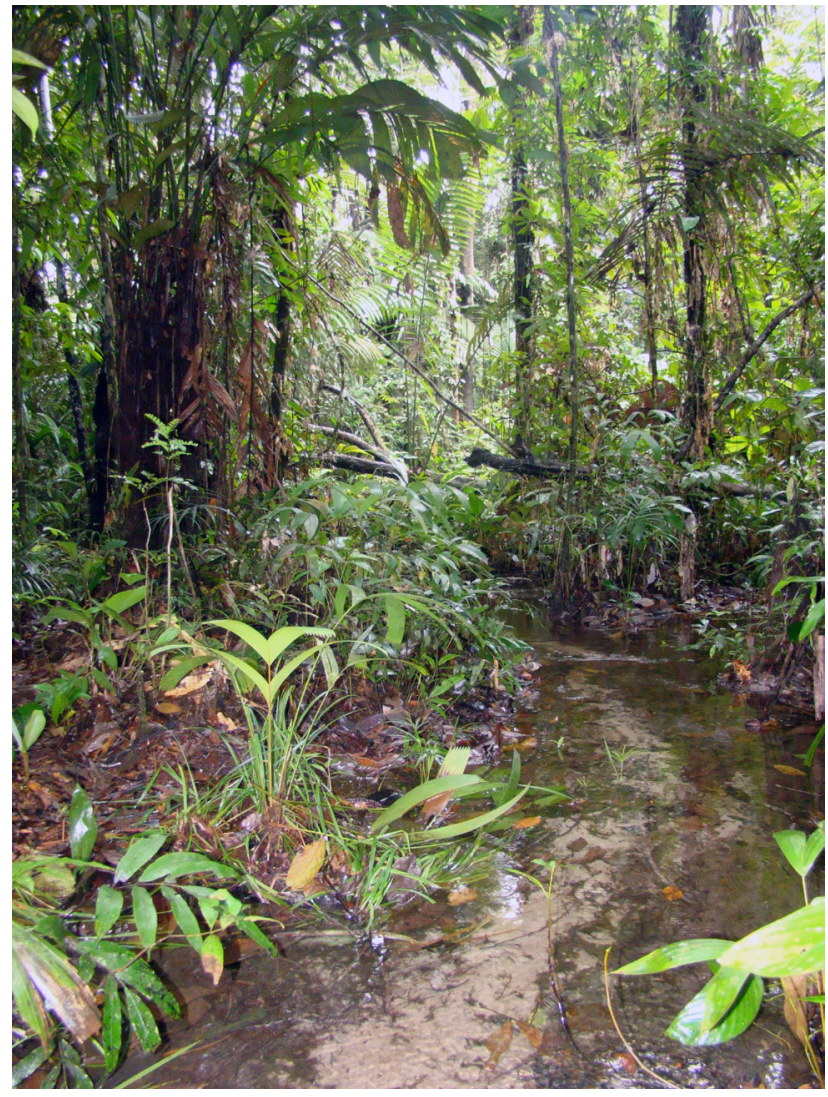

FIGURE 3. Habitat at the locality where the specimen of Amazoprhynella minuta (MHNLS 19913) was found.

1998; Péfaur and Rivero 2000; Señaris and Rivas 2006) and $A$. minuta is widely distributed in the Amazon and Guiana regions (Ávila et al. 2012; Fouquet et al. 2012; Frost 2013). The northern region of Amazonas state, Venezuela, has been sampled on multiple occasions during the last two centuries by professional herpetologists so the fact that so far only one specimen of $A$. minuta has been found probably indicates that this small toad occurs at very low densities.
Some authors have suggested that Amazophrynella minuta currently represents a complex of cryptic species (Fouquet et al. 2007; 2012; Ávila et al. 2012). However, additional detailed work, preferably including several lines of evidence (e.g. morphological, molecular, behavioral, ecological), is necessary to assess the taxonomic status of the populations of toads currently assigned to this taxon.

ACKNOWheDgments: We thank J. Celsa Señaris and Fundación La Salle de Ciencias Naturales for their logistic support. Also we are indebted to Ross MacCulloch and J. Celsa Señaris for improving an earlier draft of this work with helpful comments.

\section{Literature Cited}

Ávila, R.W., V.T. de Carvalho, M. Gordo, R.A. Kawashita-Ribeiro and D.H. Morais. 2012. A new species of Amazophrynella (Anura: Bufonidae) from southern Amazonia. Zootaxa 3484: 65-74.

Barrio-Amorós, C.L. 1998. Sistemática y biogeografía de los anfibios (Amphibia) de Venezuela. Acta Biologica Venezuelica 18(2): 1-93.

Fouquet, A., A. Gilles, M. Vences, C. Marty, M. Blanc, and N.J. Gemmell. 2007. Underestimation of species richness in Neotropical frogs revealed by mtDNA analyses. PLoS ONE 2(10): 1-10.

Fouquet, A., R. Recoder, M. Texeira Jr., J. Cassimiro, R.C. Amaro, A. Camacho, R. Damasceno, A.C. Carnaval, C. Moritz and M.T. Rodrigues. 2012. Molecular phylogeny and morphometric analyses reveal deep divergence between Amazonia and Atlantic Forest species of Dendrophryniscus. Molecular Phylogenetics and Evolution 62(3): 826838.

Frost, D.R. 2013. Amphibian species of the world: an online reference. Version 5.6 (9 January 2013). American Museum of Natural History, New York, USA. Electronic Database accessible at http://research. amnh.org/herpetology/amphibia/index.html. Captured on 18 February 2013.

Péfaur J.E. and J.A. Rivero. 2000. Distribution, species-richness, endemism, and conservation of Venezuelan amphibians and reptiles. Amphibian and Reptile Conservation 2(2): 42-70.

Señaris, J.C. and G. Rivas. 2006. Herpetofauna de la confluencia de los ríos Orinoco y Ventuari, estado Amazonas, Venezuela; p. 129-135 In C.A. Lasso, J.C. Señaris, L.E. Alonso and A.L. Flores (ed.). Evaluación rápida de la biodiversidad de los ecosistemas acuáticos en la confluencia de los ríos Orinoco y Ventuari, estado Amazonas (Venezuela). Boletín RAP de Evaluación Biológica 30. Washington DC: Conservación Internacional

RECEIVED: April 2013

ACCEPTED: August 2013

Published online: October 2013

EDITORIAL RESPONSIBILITY: Ross MacCulloch 